\title{
Integrated genetic map of citrus based on RAPD markers
}

\author{
Roberto Pedroso de OLIVEIRA ${ }^{a *}$, Mariângela Cristofani ${ }^{b}$, Marcos Antonio MACHAdo ${ }^{b}$
}

\author{
a Embrapa-Centro de Pesquisa \\ Agropecuária de Clima \\ Temperado (CPACT), \\ PO Box 403, 96001-970, \\ Pelotas-RS, Brazil \\ rpedroso@cpact.embrapa.br \\ ${ }^{b}$ Centro APTA Citros 'Sylvio \\ Moreira' / IAC, PO Box 04, \\ 13490-970, Cordeirópolis-SP, \\ Brazil
}

${ }^{*}$ Correspondence and reprints

Fruits, 2005, vol. 60, p. 187-193 (C) $2005 \mathrm{Cirad} /$ EDP Sciences All rights reserved DOI: 10.1051/fruits:2005025

RESUMEN ESPAÑOL, p. 193

\section{Integrated genetic map of citrus based on RAPD markers.}

Abstract - Introduction. The citrus industry is one of the main activities of Brazilian agriculture. Several pests and diseases have threatened citrus culture in recent years. Genetic mapping is one of the most efficient strategies for conducting advanced genetic studies by facilitating plant selection guided by markers. The objective of this study was to construct an integrated genetic map between Citrus sinensis (L.) Osbeck cv. 'Pêra' and C. reticulata Blanco $\mathrm{cv}$. 'Cravo' using two different types of segregation of markers. Materials and methods. The linkage analyses were conducted with segregation data obtained from 256 RAPD markers in a population of 94 hybrids. Analyses were performed through the software JoinMap, LOD $\geq 6.0$, $\theta \leq 0.25$, and the Kosambi function. Results and discussion. The linked map between the two cultivars had 217 markers defined by 15 linkage groups, covering $527 \mathrm{cM}$. This map had five linkage groups with common markers of 'Pêra' and 'Cravo'. The inclusion of new markers would increase the number of linkage groups with markers from both parents, thus making their number equal to the haploid chromosome number. The alterations in the order and in the distances among the markers, due to the presence or absence of bridging markers in the linkage map, are discussed.

Citrus reticulata / Citrus sinensis / genetic maps / genetic markers / RAPD

\section{Carte génétique intégrée des agrumes, basée sur l'utilisation de marqueurs RAPD.}

Résumé - Introduction. L'industrie des agrumes est l'une des activités principales de l'agriculture brésilienne. Plusieurs ravageurs et maladies ont menacé cette culture ces dernières années. La cartographie moléculaire est l'une des stratégies les plus efficaces pour entreprendre des études génétiques avancées afin de faciliter une sélection des plants assistée par marqueurs. L'objectif de cette étude a été de construire une carte génétique intégrée entre Citrus sinensis (L.) Osbeck cv. 'Pêra' et C. reticulata Blanco cv. 'Cravo' en utilisant deux types différents de ségrégation des marqueurs. Matériel et méthodes. Les analyses de liaisons ont été conduites à partir de données de ségrégation obtenues de 256 marqueurs RAPD dans une population de 94 hybrides. Les analyses ont été réalisées avec le logiciel JoinMap. Résultats et discussion. La carte des liaisons entre l'un et l'autre des cultivars a comporté 217 marqueurs définis par 15 groupes de liaisons, couvrant 527 cM. Cette carte a présenté cinq groupes de liaisons contenant les marqueurs communs de Pêra et Cravo. L'inclusion de nouveaux marqueurs augmenterait le nombre de groupes de liaisons portant des marqueurs des deux parents, en rendant leur nombre égal au nombre de chromosomes haploïde. Les différences d'ordre et de distances au sein des marqueurs, dues à la présence ou à l'absence de marqueurs dans la carte de liaisons, sont discutées.

Citrus reticulata / Citrus sinensis / carte génétique / marqueur génétique / RAPD 


\section{Introduction}

The citrus industry is one of the main activities of Brazilian agriculture. Besides supplying the national market, the export of orange juice and its sub-products amount to 1.5 billion dollars in annual revenues [1].

Several pests and diseases have threatened citrus culture in recent years. Citrus cultivation is considered a monoculture due to the large area that it occupies. Moreover, industry is based upon a limited number of suitable varieties for canopy and rootstocks.

Even though breeding has been conducted in citrus since the xixth century, only a small number of varieties have resulted. These plants are recalcitrant to genomic research because of their high genetic heterozygosity, resulting from outcrossing and long generation times [2]. In addition, little is known about genetic inheritance of the main agronomic traits of citrus [3].

Genetic mapping is one of the most efficient strategies for conducting advanced genetic studies by facilitating plant selection guided by markers, and by the understanding of inheritance, structure and organization of genes. Moreover, genetic mapping also assists studies of evolution, introgression, identification and gene isolation $[4,5]$. Once isolated, genes can be cloned and transferred to commercial varieties through genetic transformation, thus overcoming biological barriers that exist in Citrus species [6].

Citrus has advantageous characteristics that help with the construction of genetic maps. They are diploid with a low haploid chromosome number $(n=9)$, highly polymorphic; they easily allow the production of interspecific and intergeneric hybrids, and they have small genomes [7]

Several citrus genetic mapping projects have been conducted in the world with the purpose of identifying genes and/or quantitative trait loci (QTL) for resistance/tolerance to salts and cold [8], tristeza virus [9], dormancy, juvenility and vigor [10], and plant height and fruit acidity [6].

Numerous softwares have been utilized for the construction of linkage maps of different species, such as MapMaker, Linkage1, GMendel and JoinMap. The JoinMap is based upon a LOD modified in function of an independent Chi-square test of segregation data, thus allowing the integration of markers of different types of segregation in parental maps and the construction of consensus maps [11].

In the last few years, integrated maps of several species have been published [1214]. Due to an increase in the loci density and a decrease in the number of gaps, these consensus maps can give a more precise identification of major genes and/or QTLs of agronomic importance. In addition, they can help to conduct the selection guided by markers and to study the organization of the genome as well as the level of chromosomal rearrangement within the species.

The objective of this study was to construct an integrated genetic linkage map between Citrus sinensis (L.) Osbeck cv. 'Pêra' and C. reticulata Blanco cv. 'Cravo', using two different types of segregation of RAPD markers

\section{Materials and methods}

\subsection{Plant material}

The cultivars C. reticulata Blanco 'Cravo' and $C$. sinensis (L.) Osbeck 'Pêra' and $94 \mathrm{~F}_{1}$ hybrid progeny were studied. The hybrid population was differentiated from the nucellar plants with morphologic and RAPD markers according to Oliveira et al. [15].

\subsection{DNA extraction and RAPD assay}

The DNA extraction and the RAPD analyses were conducted according to Oliveira et al. [16]. Ninety-seven decamer primers of arbitrary sequences were used from the following Operon Technologies Inc. (Alameda, CA, USA) kits: A, AB, AT, AV, B, C, D, E, G $\mathrm{H}, \mathrm{I}, \mathrm{M}, \mathrm{N}, \mathrm{P}, \mathrm{Q}, \mathrm{R}, \mathrm{U}$ and $\mathrm{Y}$. The primers of the kits were arbitrarily chosen.

\subsection{Statistical analysis}

Amplified fragments that segregated in the progeny were selected as markers. Depending on the type of segregation in the hybrid 
progeny, markers were classified as: (a) heterozygous loci in 'Cravo' mandarin and recessive homozygous loci in 'Pêra' sweet orange $(\mathrm{lm} \times 1 \mathrm{l})$; (b) recessive homozygous loci in 'Cravo' mandarin and heterozygous loci in 'Pêra' sweet orange $(n n \times n p)$; and c) heterozygous loci in both parents (hk $\times \mathrm{hk}$ ).

Through chi-square analyses $\left(\chi^{2}, \rho<\right.$ 0.05 , DF $=1$ ), the null hypothesis of Mendelian segregation 1:1 was tested for each one of the markers that had the segregation types $(\mathrm{lm} \times 1 \mathrm{l})$ and $(\mathrm{nn} \times \mathrm{np})$, while the hypothesis of segregation 3:1 was done for markers $(\mathrm{hk} \times \mathrm{hk})$.

Linkage analyses were conducted using the software JoinMap v.3.0 [11], since the hybrid population was from the crossing between two diploid, heterogeneous and heterozygous parents. Based upon the segregation of markers found in the progeny, a linkage map was constructed. An integrated map of the parents was obtained by analyzing together the markers from the three types of configurations [ $(\operatorname{lm} \times 11),(n n \times$ $\mathrm{np})$ and $(\mathrm{hk} \times \mathrm{hk})]$. In this case, loci that were heterozygous in both parents were used as bridges to integrate markers. The criteria used to map were LOD $\geq 6.0$ and $\theta \leq$ 0.25 . Linkage consistency was evaluated by testing the minimal scores of LOD of 3.0, 4.0, 5.0 and 7.0 , and maximal recombination frequencies of 0.30 and 0.40 . The JoinMap functions jump, ripple and triplet were used to organize marker order better in linkage groups [11]. The Kosambi function [17] was used for conversion of recombination fractions to values referring to map distances in centiMorgan (cM). In the map only linkage groups with more than three markers were considered.

\section{Results and discussion}

RAPD analyses resulted in amplification of 256 loci with polymorphism in hybrid progeny. Based upon segregation analyses of these markers in the progeny, we concluded that 123 markers (48.0\%) were heterozygous in 'Cravo' mandarin and recessive homozygous in 'Pêra' sweet orange; 53 markers (20.7\%) were heterozygous in 'Pêra' and recessive homozygous in 'Cravo'; and
80 markers (31.3\%) were heterozygous in both parents. The high percentage of heterozygous common markers in both parents suggests that genetic similarity was high between the 'Cravo' mandarin and 'Pêra' sweet orange. This result was expected because taxonomically these cultivars are classified as very closely related [18], and many authors hypothesize that $C$. sinensis was derived from $C$. reticulata. According to Federici et al. [19], C. sinensis must be a hybrid obtained from the crossing between C. maxima (pummelos) and C. reticulata (mandarins).

Heterozygous markers found in both parents showed a uniform distribution in the linkage groups, without any cluster formation. Therefore, these markers were found in all of the linkage groups of the 'Cravo' mandarin. In the case of 'Pêra' sweet orange, only the linkage group VII was an exception. Inclusion of markers heterozygous in both parents significantly increased the number of markers of the maps of 'Pêra' sweet orange and 'Cravo' mandarin, when compared with the study conducted by Oliveira [20]. This fact leads to a more precise identification of genes and/or QTLs of agronomic importance [21].

The literature reports skewed segregation markers in genetic linkage maps at several levels at intergeneric as well as intraspecific hybrids with values between 3.9\% [22] and $100 \%$ [23]. In this study, markers of 'Pêra' sweet orange, which were heterozygous in one of the parents and recessive homozygous in the other parent, showed $61.5 \%$ of skewed segregation and $25.5 \%$ in 'Cravo' mandarin, when compared with the expected 1:1 Mendelian segregation $(p<0.05)$. Heterozygous markers from both parents showed $40 \%$ frequency of skewed segregation to the expected 3:1 Mendelian segregation $(p<0.05)$. Tanksley et al. [24] suggest that chromosome rearrangements and zygotic and/or post-zygotic gamete selection may cause skewed segregation in several species.

The integrated map of Citrus had 217 markers assembled in 15 linkage groups and represented a total length of $527 \mathrm{cM}$. Linkage groups had 112 (51.6\%) heterozygous markers from 'Pêra' sweet orange, 44 (20.3\%) heterozygous markers from 'Cravo' 
Figure 1. Integrated genetic linkage map between C. sinensis (L.) Osbeck cv. 'Pêra' and C. reticulata Blanco cv. 'Cravo'. The linkage relationships of 217 RAPD markers were established with LOD $\geq 6.0$ and $\theta \leq 0.25$.

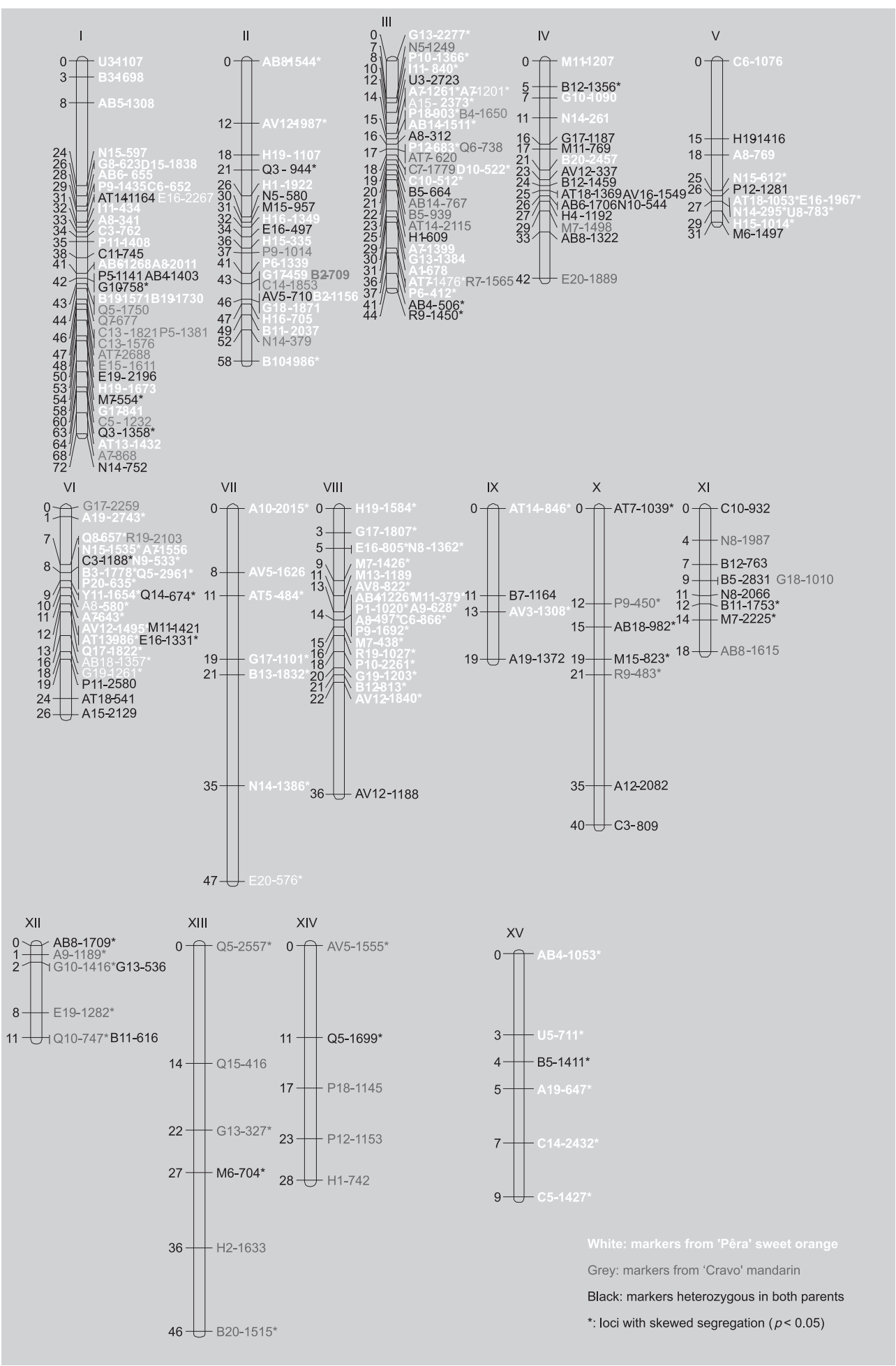


mandarin and 61 (28.1\%) heterozygous markers from both parents. The distance between adjacent markers varied from 0 to $16 \mathrm{cM}$, with an average of $2.4 \mathrm{cM}$, and 11 gaps had distances greater than $10 \mathrm{cM}$. The majority of these gaps (63.6\%) occurred in linkage groups with less than 10 markers (figure 1).

The number of linkage groups obtained from the integrated map was much higher than the chromosome haploid number for the genus Citrus. Only five linkage groups (I, II, III, IV and VI) had common markers from 'Pêra' sweet orange and 'Cravo' mandarin, thus resulting in the integration of the maps (figure 1). Inclusion of more bridging markers would certainly favor the linking of some of the existent groups, which could lower the number of groups to equal the chromosome haploid number [12, 13].

Analyses of heterozygous markers in both parents allow inference of existing homology between linkage groups of 'Pêra' sweet orange and 'Cravo' mandarin. Homology of five linkage groups (I, II, III, IV and VI) was confirmed by the presence of at least four markers, which showed a highly conserved arrangement, but with significant variation in the recombination frequencies. Hemmat et al. [21] observed a conserved organization of the genome of the species studied and that recombination frequencies for specific segments of maps differ between the parents.

The integrated map of Citrus (527 cM) was much larger than those of 'Cravo' mandarin (313 cM) and 'Pêra' sweet orange (377 cM) [20]. This was probably due to the fact that only five linkage groups showed integration of markers from maps of 'Cravo' mandarin and 'Pêra' sweet orange (figure 1). Even with this reduced level of integration, the mean distance between adjacent markers $(2.4 \mathrm{cM})$ did not increase, and this value was much lower than that observed in the map of 'Cravo' mandarin $(3.3 \mathrm{cM})$.

Comparison analyses of the three maps on the linkage groups responsible for the integration of markers of 'Pêra' sweet orange and 'Cravo' mandarin showed a somewhat conserved arrangement of markers and significant alteration in the recombination fre- quencies. According to Durham et al. [4], this result was expected, due to the fact that interspecific fertile hybrids are easily obtained in Citrus. On the other hand, these authors mentioned that differences in the order of the markers were also expected, such as the ones observed in group VI of the integrated map, because of the large number of loci with skewed segregation. The limitations of the software and of the dominant nature of the markers used for mapping analyses can also cause incorrect arrangements. Data collected by Jacobs et al. [12] showed that it is difficult to obtain a correct order in regions with a high concentration of markers in the maps. Another limitation to the precise order of the markers is the use of dominant markers, which are less informative and can cause ambiguity [5, 21, 25].

Studies are now being conducted to include co-dominant markers as microsatellites and RFLP in this integrated map.

\section{Acknowledgements}

We gratefully acknowledge the Conselho Nacional de Desenvolvimento Científico e Tecnológico (CNPq) for financial support for the project.

\section{References}

[1] Anon., Mapeamento da fruticultura brasileira, Minist. Agric. do Abast., Brasilia, Brasil, 2000.

[2] Wu R.L., Zeng Z.B., McKeand S.E., O’Malley D.M., The case for molecular mapping in forest tree breeding, Plant Breed. Rev. 19 (2000) 41-68.

[3] Grosser J.W., Gmitter F.G. Jr., Somatic hybridization of Citrus with wild relatives for germplasm enhancement and cultivar development, HortScience 25 (1990) 147-151.

[4] Durham R.E., Liou P.C., Gmitter F.G. Jr., Moore G.A., Linkage of restriction fragment length polymorphisms and isozymes in Citrus, Theor. Appl. Genet. 84 (1992) 39-48.

[5] Roose M.L., Fang D., Cheng F.S., Tayyar R.I, Federici C.T., Kupper R.S., Mapping the Citrus genome, Acta Hortic. 535 (2000) 25-32. 
[6] Gmitter F.G. Jr., Xiao S.Y., Huang S., Hu X.L., Garnsey S.M., Deng Z., A localized linkage map of the virus tristeza virus resistance gene region, Theor. Appl. Genet. 92 (1996) 688-695.

[7] Guerra M.S., Cytogenetics of Rutaceae. II. Nuclear DNA content, Caryologia 37 (1984) 219-226.

[8] Moore G.A., Tozlu I., Weber, C.A., Guy C.L., Mapping quantitative trait loci for salt tolerance and cold tolerance in Citrus grandis (L.) Osb. $\times$ Poncirus trifoliata (L.) Raf. hybrid populations, Acta Hortic. 535 (2000) 37-45.

[9] Cristofani M., Machado M.A., Grattapaglia D., Genetic linkage maps of Citrus sunk Hort. ex. Tan. and Poncirus trifoliata (L.) Raf. and mapping of citrus tristeza virus resistance gene, Euphytica 109 (1999) 25-32.

[10] Roose M.L., Jarrell D.C., Kupper R.S., Genetic mapping in a Citrus $\times$ Poncirus $\mathrm{F}_{2}$ population, Proc. Int. Soc. Citriculture 7 (1992) 210213.

[11] Van Ooijen J.W., Voorrips R.E., JoinMap® Version 3.0, software for the calculation of genetic linkage maps (software), Plant Res. Int., Wageningen, Nederland, 2001.

[12] Jacobs J.M.E., Van Eck H.J., Arens P., VerkerkBakker B., Lintel-Hekkert B., Bastiaansen H.J.M., El-Kharbotly A., Pereira A., Jacobsen E., Stiekema W.J., A genetic map of potato (Solanum tuberosum) integrating molecular markers, including transposons and classical markers, Theor. Appl. Genet. 91 (1995) 289-300.

[13] Qi X., Stam P., Lindhout P., Comparison and integration of four barley genetic maps, Theor. Appl. Genet. 93 (1996) 234-241.

[14] Sebastian R.L., Howell E.C., King G.J., Marshall D.F, Kearsey M.J., An integrated AFLP and RFLP Brassica oleracea linkage map from two morphologically distinct doubled-haploid mapping populations, Theor. Appl. Genet. 100 (2000) 75-81.

[15] Oliveira R.P., Novelli V.M., Machado M.A., Freqüência de híbridos em cruzamento entre tangerina 'Cravo' e laranja 'Pêra': análise de marcadores morfológicos e RAPD, Pesqui. Agropecu. Brasil. 35 (2000) 1895-1903.
[16] Oliveira R.P., Cristofani M., Aguilar-Vildoso C.I., Machado M.A., Diversidade genética entre híbridos de tangerina 'Cravo' e laranja 'Pêra' utilizando marcadores RAPD, Pesqui. Agropecu. Brasil. 37 (2002) 479-484.

[17] Kosambi D.D., The estimation of map distance from recombination values, Ann Eugenet. 12 (1944) 172-175.

[18] Davies F.S., Albrigo L.G., Citrus, CAB Int., Wallingford, UK, 1994.

[19] Federici C.T., Fang D.Q., Scora R.W., Roose M.L., Phylogenetic relationships within the genus Citrus (Rutaceae) and related genera as revealed by RFLP and RAPD analyses, Theor. Appl. Genet. 96 (1998) 812-822.

[20] Oliveira R.P., Mapping of 'Pêra' sweet orange (Citrus sinensis L. Osbeck) and 'Cravo' mandarin (C. reticulata Blanco) by pseudo-testcross, Univ. São Paulo, Thesis, Piracicaba, Brazil, 2001, 181 p.

[21] Hemmat M., Weeden N.F. Manganaris A.G., Lawson D.M., Molecular marker linkage map for apple, J. Hered. 85 (1994) 4-11.

[22] Grattapaglia D., Sederoff R., Genetic linkage maps of Eucalyptus grandis and Eucalyptus urophylla using a pseudo-testcross: mapping strategy and RAPD markers, Genetics 137 (1994) 1121-1137.

[23] Nienhuis J., Helentjaris T., Slocum M., Ruggero B., Schaefer A., Restriction fragment length polymorphism analysis of loci associated with insect resistance in tomato, Crop Sci. 27 (1987) 797-803.

[24] Tanksley S.D., Ganal M.W., Prince J.P., De Vicente M.C., Bonierbale M.W., Broun P., Fulton T.M., Giovannoni J.J., Grandillo S., Martin G.B., Messeguer R., Miller J.C., Miller L., Paterson A.H., Pineda O., Roder M.S., Wing R.A., Wu W., Young N.D., High-density molecular linkage maps of the tomato and potato genomes, Genetics 132 (1992) 11411160.

[25] Cai Q., Guy C.L., Moore G.A., Extension of the linkage map in Citrus using random amplified polymorphic DNA (RAPD) markers and RFLP mapping of cold-acclimationresponsive loci, Theor. Appl. Genet. 89 (1994) 606-614. 


\section{Mapa genético integrado de citrus baseado en marcadores RAPD.}

Resumen - Introdución. La industria de citrus es una de las principales actividades de la agricultura brasileña. Diversas plagas y dolencias tienen amenazado la cultura de citrus en los años recientes. El mapeamiento genético es una de las más eficientes estrategias para conducir estudios genéticos avanzados por facilitar la selección de plantas guiadas por marcadores. El objetivo de este estudio fue construir un mapa genético integrado entre Citrus sinensis (L.) Osbeck cv. 'Pêra' y C. reticulata Blanco cv. 'Cravo', usando dos diferentes tipos de segregación de marcadores. Materiales y métodos. Las análisis de ligazón fueron conducidas con dados de segregación obtenidos de 256 marcadores RAPD en una población de 94 híbridos. Análisis fueron realizados con el software JoinMap. Resultados y discusión. El mapa ligado entrambos los cultivares tenía 217 marcadores definidos por 15 grupos de ligazón, cubriendo 527 cM. Este mapa tenía cinco grupos de ligazón con marcadores comunes de 'Pêra' y 'Cravo'. La inclusión de nuevos marcadores aumentaría el número de grupos de ligazón con marcadores de ambos los padres, haciendo sus números iguales al número del cromosoma haploide. Las alteraciones en la orden y en las distancias entre los marcadores, debido a la presencia o el ausencia de marcadores en un mapa de ligazón, son discutidos.

Citrus reticulata / Citrus sinensis / mapas genéticos / marcadores genéticos / RAPD

To access this journal online: www.edpsciences.org 